\title{
TIPOLOGI KERUSAKAN BANGUNAN AKIBAT CUACA EKSTREM STUDI KASUS CUACA EKSTREM KABUPATEN BANTUL 2019
}

\author{
Rachmat Wahyu Prabowo \\ Program Studi Arsitektur, Universitas PGRI Yogyakarta \\ rachmat@upy.ac.id
}

\begin{abstract}
The threat of disaster is unavoidable in Indonesia. In 2018, for example, 2,564 disasters occurred in which no city / district in Indonesia was free from threats. Statistical data shows that more than $90 \%$ of disasters in Indonesia are included in the hydrometeorological disaster category, which has continued to increase over the past 15 years. Even in the early half of 2020, there were 256 disasters with 99\% of them being hydrometeorological disasters such as floods, landslides and tornadoes. The existence of extreme weather events in Bantul Regency in 2019 shows that the dangers of hydrometeorology can cause considerable harm to the community. There needs to be a study to find out how to mitigate hydrometeorological disasters which are the most common hazards in Indonesia. Analysis of building damage and disaster data needs to be carried out to determine the characteristics of the impact of extreme weather on buildings, to identify building elements that are vulnerable to damage, to provide anticipatory measures and alertness to extreme weather in Indonesia. Building damage data is grouped and processed in graphical form to read information patterns as material for analysis. The results of the study show that there are things that must be done in the face of extreme weather including: choosing the quality of materials and the strength of the construction of the building, attention to building elements, especially the back of the building (kitchen \& bathroom), walls, and foundations, high vigilance in the area steep contours and highlands, need to be vigilant with all elements of society in areas of high potential for extreme weather, and the need to pay attention to vulnerable groups of the elderly and children.
\end{abstract}

Keywords: extreme weather, hydrometeorological disasters, floods, landslides, disaster mitigation

\begin{abstract}
Abstrak
Ancaman bencana menjadi hal yang tidak dapat dihindari di Indonesia. Pada tahun 2018 misalnya, terjadi 2.564 bencana dimana tidak ada kota/kabupaten di Indonesia yang bebas dari ancaman. Data statistik menunjukkan 90\% lebih kejadian bencana di Indonesia masuk dalam kelompok bencana hidrometereologi, dimana terus mengalami peningkatan selama 15 tahun terakhir. Bahkan pada awal paruh tahun 2020 ini, terjadi 256 kejadian bencana dengan 99\% merupakan bencana hidrometereologi banjir, tanah longsor \& puting beliung. Adanya kejadian cuaca ekstrem di Kabupaten Bantul pada tahun 2019 menunjukkan bahwa bahaya hidrometereologi dapat menimbulkan kerugian yang cukup besar bagi masyarakat. Perlu adanya kajian untuk mengetahui cara mitigasi bencana hidrometereologi dimana menjadi bahaya paling sering terjadi di Indonesia. Analisis data-data kerusakan bangunan dan bencana perlu dilakukan untuk mengetahui karakteristik dampak cuaca ekstrem pada bangunan, mengetahui elemen bangunan yang rentan rusak, memberikan langkah antisipasi dan kewaspadaan terhadap cuaca ekstrem di Indonesia. Data kerusakan bangunan dikelompokkan dan diolah dalam bentuk grafik untuk membaca pola-pola informasi sebagai bahan analisis. Hasil kajian menunjukkan adanya hal-hal yang harus dilakukan dalam menghadapi cuaca ekstrem diantaranya : pemilihan kualitas bahan dan kekuatan konstruksinya bangunan, perhatian pada elemen-elemen bangunan terutama bagian belakang bangunan (dapur \& kamar mandi), dinding, dan pondasi, kewaspadaan tinggi pada wilayah kontur curam dan dataran tinggi, perlu kewaspadaan bersama seluruh elemen masyarakat di wilayah potensi tinggi cuaca ekstrem, dan perlunya perhatian pada kelompok rentan usia lanjut dan anak-anak.
\end{abstract}

Kata Kunci: cuaca ekstrem, bencana hidrometereologi, banjir, tanah longsor, mitigasi bencana

\section{Pendahuluan}

Letak Negara Indonesia yang berada di bawah garis katulistiwa dan terdiri dari banyak kepulauan menjadikan Indonesia memiliki iklim tropis basah dengan ciri adanya 2 musim selama 1 tahun yaitu musim kemarau dan musim hujan dengan karakteristik perubahan cuaca, suhu, dan arah angin yang cukup ekstrem. Potensi letak geografis Indonesia tersebut berupa lahan subur yang kaya dengan flora dan fauna, juga membawa potensi bahaya hidrometereologi. Ancaman bencana menjadi hal yang tidak dapat dihindari di Indonesia. Pada tahun 2018 misalnya, terjadi 2.564 bencana dimana tidak ada kota/kabupaten di Indonesia yang bebas dari ancaman bencana (BNPB, 2018).

Bencana merupakan peristiwa atau rangkaian peristiwa yang mengancam dan mengganggu kehidupan dan penghidupan masyarakat yang disebabkan, baik oleh faktor alam dan atau faktor 
nonalam maupun faktor manusia sehingga mengakibatkan timbulnya korban jiwa manusia, kerusakan lingkungan, kerugian harta benda, dan dampak psikologis (RI, 2007). Menurut Badan Nasional Penanggulangan Bencana (BNPB, 2014) ada 12 jenis ancaman bencana di Indonesia yang dikelompokkan dalam bencana geologi (gempa bumi, tsunami, gunung api, gerakan tanah/tanah longsor), bencana hidrometereologi (banjir, kekeringan, cuaca ekstrem, gelombang ekstrem, kebakaran hutan dan lahan), dan bencana antropogenik (epidemik wabah penyakit, gagal teknologi-kecelakaan industri).

Data statistik menunjukkan 90\% lebih kejadian bencana di Indonesia masuk dalam kelompok bencana hidrometereologi, dimana terus mengalami peningkatan selama 15 tahun terakhir (Widyaningrum, 2018). Bahkan pada awal paruh tahun 2020 ini, terjadi 256 kejadian bencana dengan 99\% merupakan bencana hidrometereologi banjir, tanah longsor \& puting beliung. Meningkatnya bencana hidrometereologi sendiri diakibatkan oleh meningkatnya aktivitas manusia dan pembangunan yang mengakibatkan kerusakan lingkungan hidup dan ekosistem (BNPB, 2017). Banjir terjadi ketika debit aliran air melebihi kapasitas sungai akibat hujan yang turun di hulu atau suatu tempat secara terus menerus sehingga melimpah keluar dan menggenangi daerah sekitarnya (Paimin, Sukresno, 2009). Tanah longsor merupakan peristiwa geologi berupa perpindahan material pembentuk lereng seperti batuan, bahan rombakan tanah ataupun material campuran yang bergerak turun atau keluar lereng (Yuniarta, Saido and Muslih Purwana, 2015). Angin puting beliung adalah angin kencang berkecepatan lebih dari 34,8 Knot atau 64,4 $\mathrm{km} / \mathrm{jam}$ yang keluar dari awan cumulonimbus dan berlangsung relatif singkat (Iryanthony, 2015). Tingginya angka kejadian bencana hidrometereologi ini terutama banjir dan tanah longsor menunjukkan pentingnya perhatian dalam mengantisipasi datangnya bahaya kembali di waktu yang akan datang.

Provinsi Daerah Istimewa Yogyakarta menurut Peta Indeks Resiko Bencana memiliki nilai indeks tinggi dan merata di seluruh kota dan kabupatennya, termasuk di dalamnya Kabupaten Bantul. Pada tahun 2018 saja misalnya, di Provinsi DIY setidaknya terjadi 32 kali bencana hidrometereologi antara lain banjir 8 kali dan tanah longsor 24 kali. Kabupaten Bantul yang menjadi salah satu kabupaten Provinsi DIY masuk dalam Kelas Risiko Tinggi ancaman bencana dengan skor 187,20 (BNPB, 2018).
Tabel 1. Indeks Resiko Bencana Kab/Kota Prov. DIY

\begin{tabular}{|c|l|c|c|c|c|}
\hline No & Kab/Kota & $\mathbf{2 0 1 6}$ & $\mathbf{2 0 1 7}$ & $\mathbf{2 0 1 8}$ & $\begin{array}{c}\text { Kelas } \\
\text { Risiko } \\
\mathbf{2 0 1 8}\end{array}$ \\
\hline 1 & Kulonprogo & 203,20 & 203,20 & 203,20 & Tinggi \\
\hline 2 & Bantul & 187,20 & 187,20 & 187,20 & Tinggi \\
\hline 3 & Gunungkidul & 157,60 & 157,60 & 157,60 & Tinggi \\
\hline 4 & Sleman & 105,45 & 99,46 & 90,17 & Sedang \\
\hline 5 & Kota Yogyakarta & 80,88 & 78,46 & 73,00 & Sedang \\
\hline
\end{tabular}

(BNPB, 2018)

Pada hari Ahad 17 maret 2019, Kabupaten Bantul dilanda cuaca ekstrem berupa hujan deras yang mengguyur selama satu hari penuh. Dampak hujan sangat besar disebabkan terjadi hampir di seluruh wilayah Daerah Istimewa Yogyakarta, sehingga dirasakan juga di kabupaten dan wilayah lain. Akibatnya, banyak jalanan tergenang air dan di berbagai tempat terjadi banjir, tanah longsor, dan pohon tumbang. Dampak dari kejadian ini begitu besar sehingga membuat 4.000 lebih warga di 14 kecamatan Kabupaten Bantul mengungsi, rusaknya infrastruktur jalan, sungai, peternakan, perikanan, pertanian, pariwisata, bangunan, dan juga menimbulkan banyak korban jiwa. Badan Penanggulangan Bencana Daerah (BPBD) Kabupaten Bantul menetapkan status siaga darurat selama satu minggu untuk memprioritaskan penanganan dan pengkondisian wilayah berjalan lebih cepat dalam menghadapi bencana ini.

Adanya kejadian cuaca ekstrem di Kabupaten Bantul pada tahun 2019 menunjukkan bahwa bahaya hidrometereologi dapat menimbulkan kerugian yang cukup besar bagi masyarakat. Perlu adanya kajian untuk mengetahui cara mitigasi bencana hidrometereologi dimana menjadi bahaya paling sering terjadi di Indonesia. Tujuan mitigasi bencana adalah meminimalisis kerugian materiil dan korban jiwa yang menurut Bawono (2016) penyebab terbesarnya dari kerusakan bangunan. Analisis data-data kerusakan bangunan dan bencana perlu dilakukan untuk mengetahui karakteristik kerusakan akibat dari Banjir dan tanah longsor. Tujuan kajian data-data kerusakan bangunan adalah :

1. Mengetahui dampak cuaca ekstrem khususnya yang menyebabkan banjir \& tanah longsor pada kerusakan bangunan

2. Mengetahui elemen bangunan yang rentan rusak akibat cuaca ekstrem

3. Memberikan arahan perbaikan pada elemen bangunan yang rentan rusak, langkah antisipasi dan kewaspadaan terhadap cuaca ekstrem di Indonesia. 


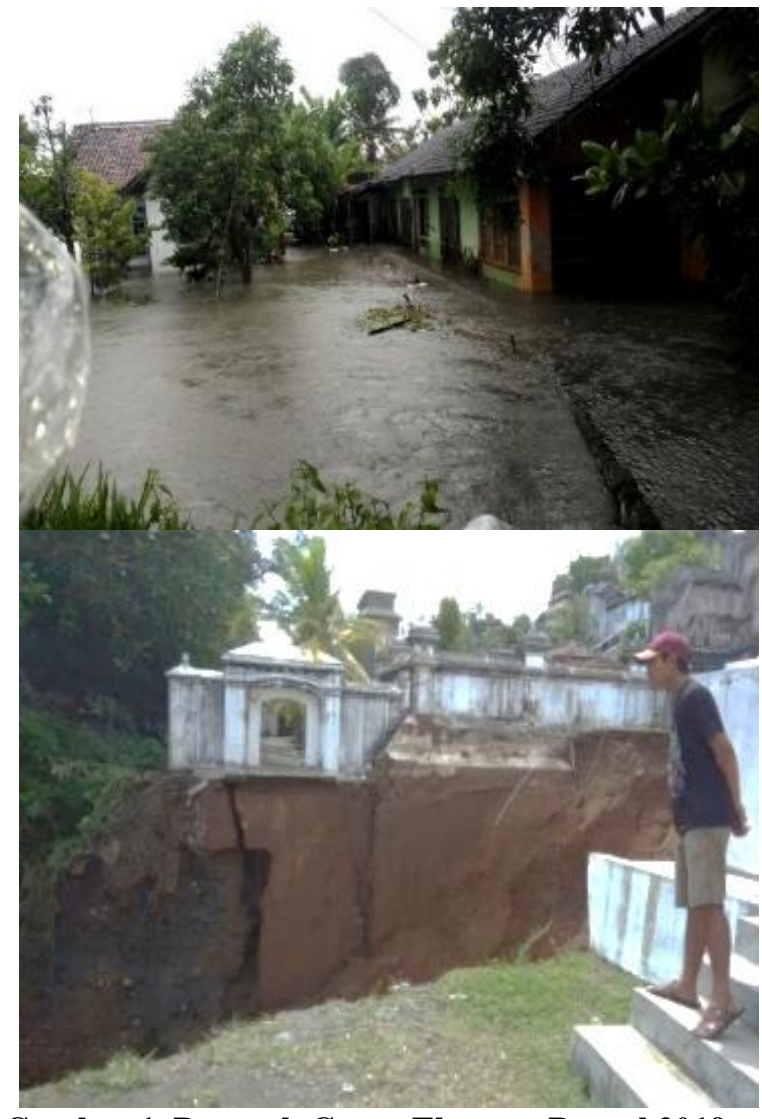

Gambar 1. Dampak Cuaca Ekstrem Bantul 2019

\section{Metode}

Data didapatkan dari hasil survei lapangan Badan Penanggulangan Bencana Daerah (BPBD) Kabupaten Bantul beberapa hari setelah bencana terjadi pada 17 maret 2019. Data kerusakan

bangunan dikelompokkan dan diolah dalam bentuk grafik untuk membaca pola-pola informasi sebagai bahan analisis selanjutnya. Pengelompokkan dan pengolahan data dilakukan dengan metode:

1. Membuat peta sebaran kerusakan

2. bangunan dan penyebab kerusakan untuk melihat sebaran dampak spasial yang terbentuk

3. Mengelompokkan tipe-tipe dan tingkat kerusakan bangunan untuk melihat karakteristik kerusakan bangunan.

Grafik dan angka yang diperoleh dianalisis dengan melihat data dan informasi pendukung lainnya. Hasil analisis dijelaskan secara deskriptif untuk menguraikan bagaimana fenomena dapat terjadi. Proses analisis dilihat untuk membaca karakteristik kerusakan bangunan yang ada dalam menentukan langkah mitigasi dampak dalam rangka meminimalisir kerugian materiil dan korban jiwa akibat bahaya cuaca ekstrem khususnya banjir dan tanah longsor.
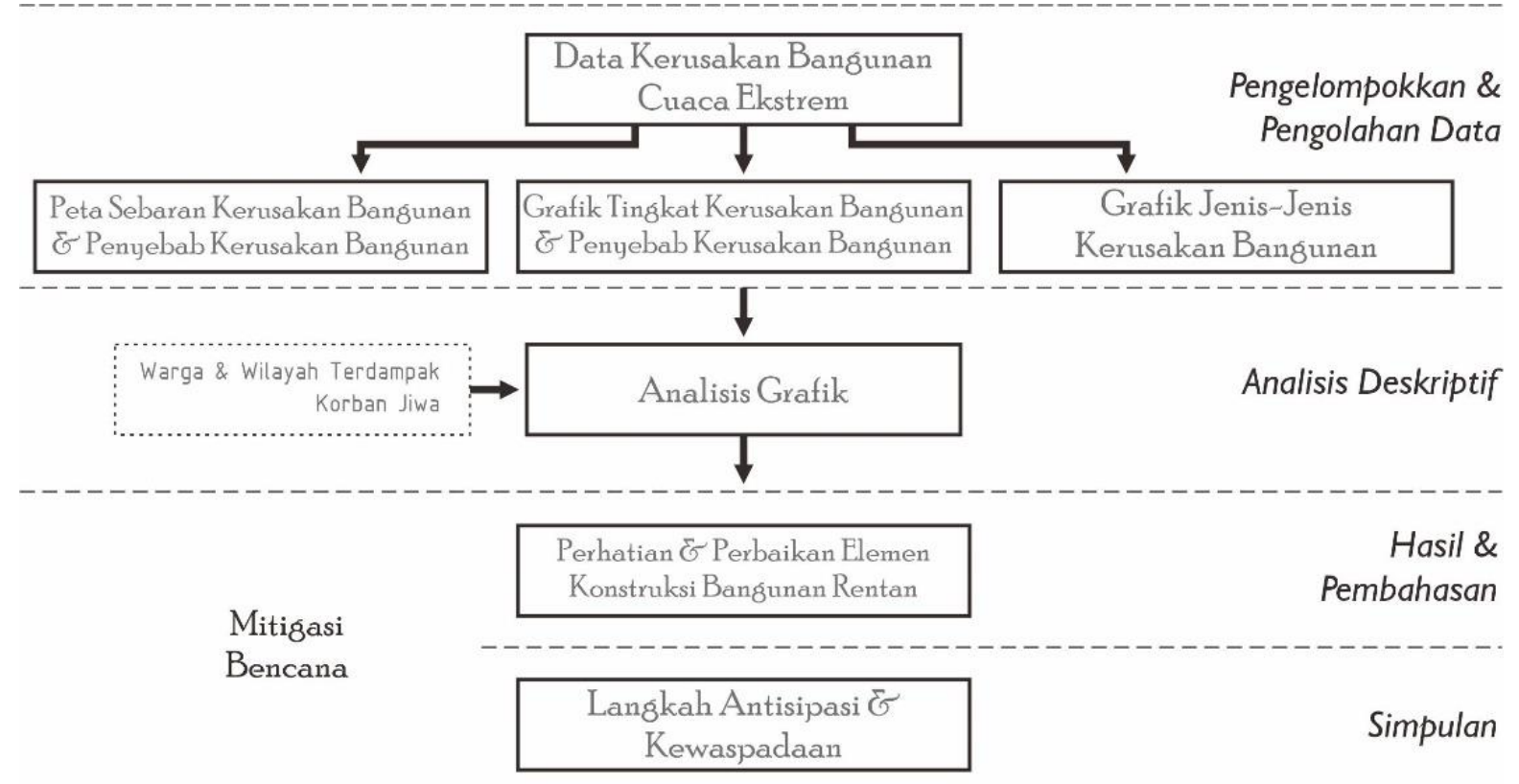

\section{Gambar 2. Diagram Berpikir}

\section{Hasil dan Pembahasan}

Kabupaten Bantul memiliki luas 506,85 km² terbagi atas 17 kecamatan (Kapanewon) dan 75 kalurahan. Cuaca ekstrem memberi dampak kepada 24 kalurahan di 10 kecamatan berbeda meliputi 3.746 kepala keluarga yang terdiri 16.286 warga. Bangunan-bangunan dan infrastruktur sosial terendam air dan rusak akibat banjir, tanah longsor, pohon tumbang, dan angin kencang. Bidang usaha, pertanian, perikanan, peternakan, pariwisata, dan sekolah mengalami kerusakan sarana dan prasarana serta kerugian akibat kejadian ini. Tercatat 56 bangunan rusak dan 8 orang menjadi korban yang diantaranya 5 meninggal dunia. 


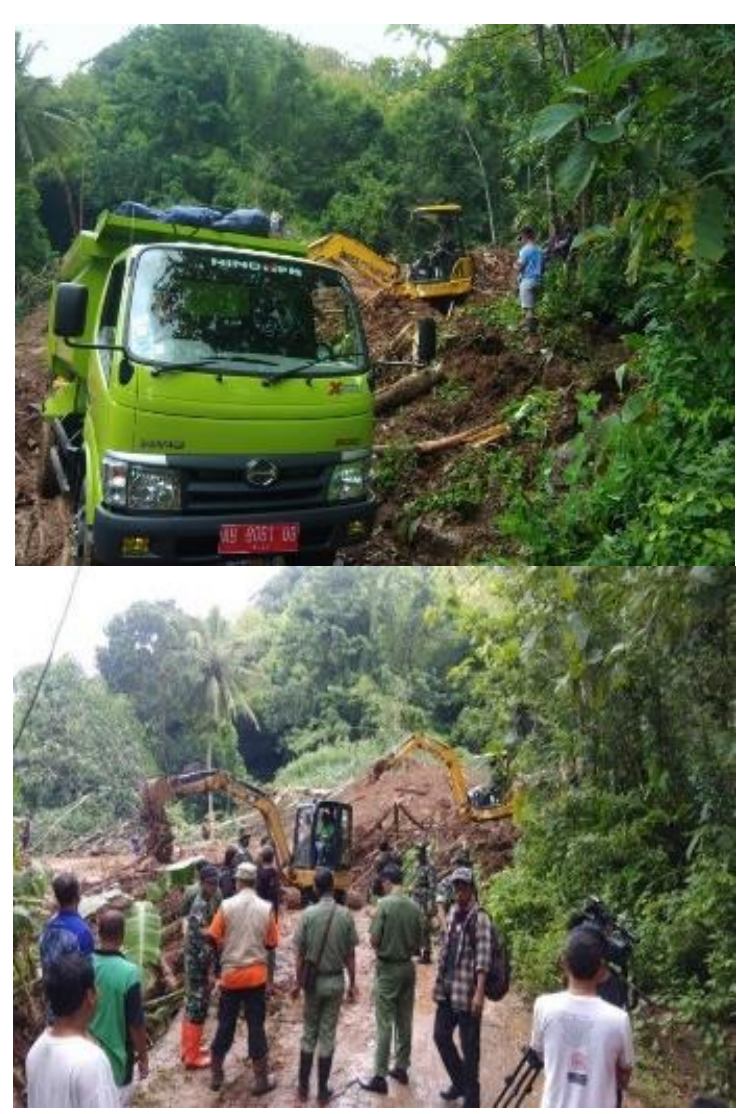

Gambar 3. Proses Penyelamatan dan Evakuasi Bencana Cuaca Ekstrem Bantul

\section{Sebaran Dampak \& Kerusakan Bangunan}

Hasil pengelompokkan dan pengolahan data mendapatkan pola sebaran kerusakan bangunan yang tidak merata secara spasial wilayah. Gradasi warna hijau sampai merah pada peta (Gambar 5) menunjukkan perbedaan jumlah kerusakan bangunan. Kerusakan bangunan disebabkan oleh kondisi banjir, tanah longsor, pohon tumbang, dan angin kencang ditunjukkan melalui perbedaan arsir pada peta. Daerah kerusakan cenderung mengelompok di wilayah bagian timur atau Kapanewon Imogiri dimana merupakan daerah dataran tinggi dan kelerengan terjal (Gambar 6). Terdapat 5 kalurahan di Kapanewon Imogiri yang terdampak kerusakan bangunan yaitu Kalurahan Girirejo, Karangtengah, Selopamioro, Sriharjo, dan Wukirsari. Kerusakan paling banyak terjadi di Kalurahan Sriharjo mencapai lebih dari 15 rumah.

Dari 75 kalurahan di Kabupaten Bantul, terdapat 24 kalurahan terdampak cuaca ekstrem. Wilayah kelurahan terdampak tidak semuanya mengalami kerusakan bangunan. 8 kalurahan terdampak tidak terdapat kerusakan bangunan antara lain Argosari, Banguntapan, Jatimulyo, Karangtalun, Kebon Agung, Srihardono, Sidomulyo, dan Tirtosari (Gambar 4). Letak 8 kelurahan tersebut rata-rata berada di dataran rendah dan kontur yang relatif landai.
Cuaca ekstrem juga mengakibatkan beberapa korban yaitu 3 korban cedera dan 5 korban jiwa. Dilihat dari sebaran korban, semua korban cedera dan korban jiwa berasal dari Kalurahan Kapanewon Imogiri yang menjadi wilayah terdampak paling berat dengan rincian 3 korban cedera semua dari Kalurahan Wukirsari, sedangkan 5 korban meninggal 3 dari Kalurahan Wukirsari dan 1 dari Kalurahan Karang Tengah (Gambar 5). Jika dilihat dari kelompok usia, korban meninggal terdiri 4 orang dari kelompok usia lanjut (lebih dari 50 tahun) dan 1 anak-anak (usia 9 tahun). Melihat kondisi tersebut dapat dilihat bahwa usia lanjut dan anak-anak menjadi kelompok yang cukup rentan menjadi korban bahaya cuaca ekstrem.

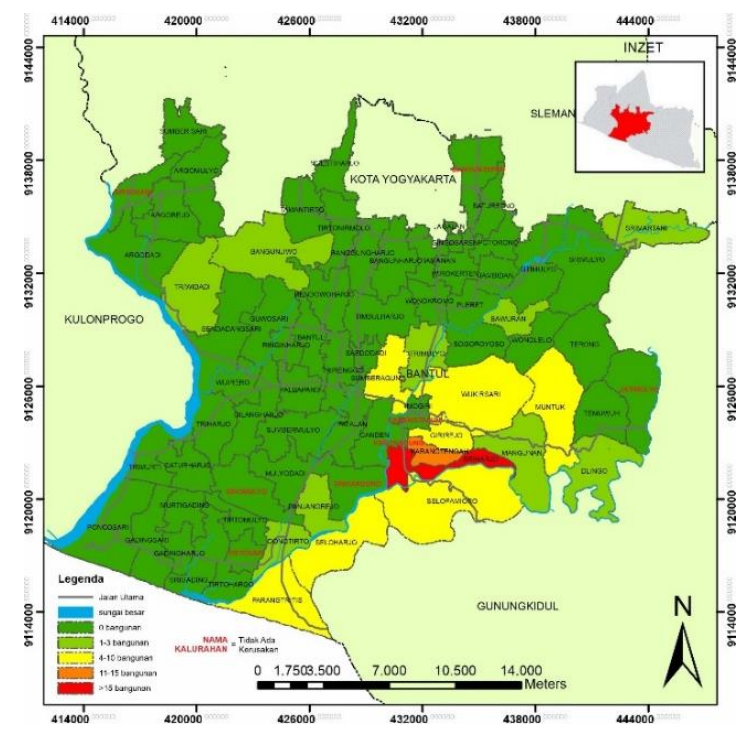

Gambar 4. Peta Sebaran Dampak

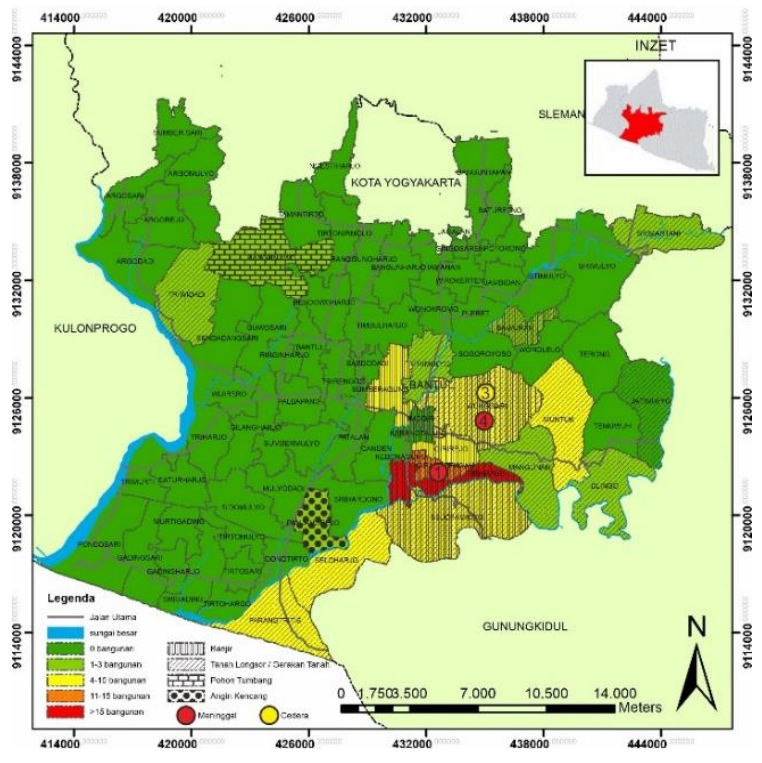

Gambar 5. Peta Sebaran Kerusakan Bangunan \& Korban Jiwa 


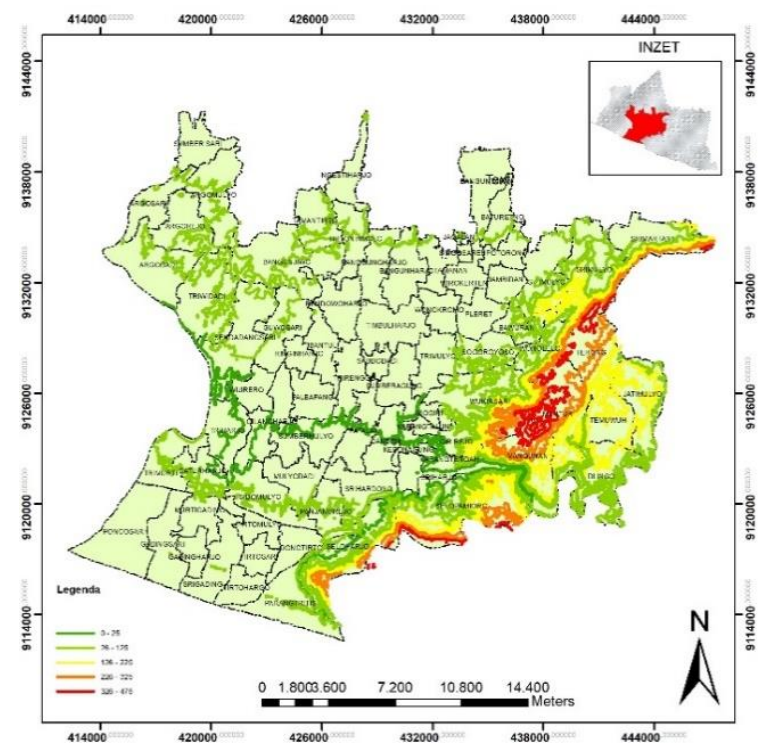

Gambar 6. Peta Kontur Kabupaten Bantul

\section{Tipologi Kerusakan Bangunan}

Data kerusakan bangunan dibagi menjadi 4 kelompok berdasarkan persentase : Ringan (1\%$24 \%)$, Sedang (25\%-49\%), Berat (50\%-90\%), dan Rusak Total (90-100\%). Pembagian kelompok persentase mendapatkan angka tingkat kerusakan cukup beragam antara lain : level ringan dengan persentase $55,36 \%$, sisanya level sedang $25 \%$, $1,79 \%$ rusak berat, dan 17,86 rusak total. Dilihat dari angka, kerusakan sedang sampai rusak total mencapai hampir setengah $(44,64 \%)$ menunjukkan kejadian cuaca ekstrem bisa sangat destruktif pada bangunan.

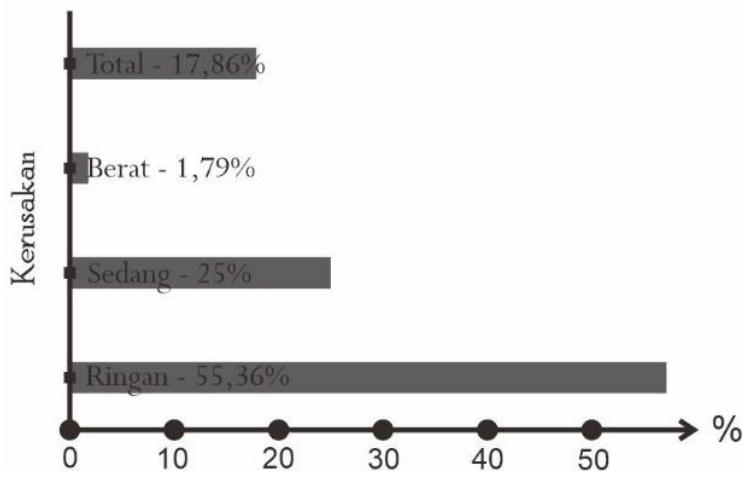

Gambar 7. Tingkat Kerusakan Bangunan

Cuaca ektrem mengakibatkan perubahan kondisi geografis setempat secara tiba-tiba sehingga dapat merusak lingkungan binaan, infrastruktur, dan bangunan. Kerusakan bangunan yang terjadi disebabkan oleh banjir, tanah longsor, pohon tumbang dan angin kencang. Banjir dan tanah longsor menjadi penyebab utama kerusakan bangunan. Grafik menunjukkan tanah longsor sangat merusak bangunan dengan angka $75 \%$, sedangkan banjir 21,43\%. Melihat data korban jiwa, kejadian cuaca ekstrem mengakibatkan 5 korban jiwa dimana 2 korban disebabkan banjir dan 3 korban disebabkan tanah longsor. Cuaca ekstrem yang sering terjadi mengarah pada turunnya hujan terus menerus yang cukup lama. Sistem drainase dan infrastruktur yang belum disiapkan dengan baik dalam menyalurkan limpasan air hujan kemudian bisa menimbulkan genangan air di area datar dan pergerakan tanah di area dataran tinggi dan berkontur.

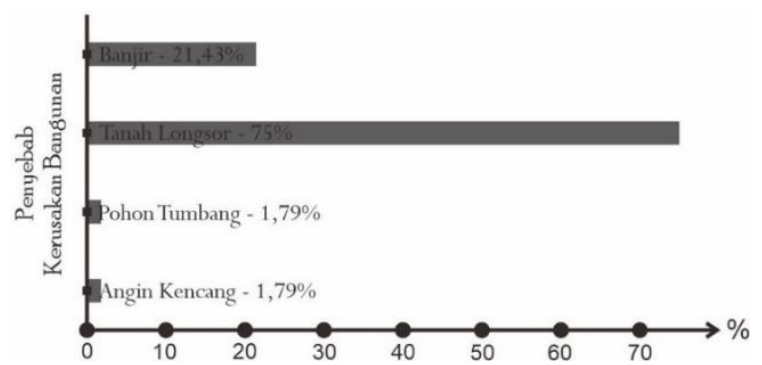

Gambar 8. Penyebab Kerusakan Bangunan

Karakter kerusakan bangunan membentuk konfigurasi komponen bangunan sederhana yang terbagi ke dalam 4 bagian elemen bangunan secara vertikal (Gambar 9) dan horizontal (Gambar 10). Kerusakan elemen bangunan secara vertikal terbagi menjadi : bagian bawah (pondasi), tengah (dinding), atap (atas), dan seluruh bangunan (total). Sedangkan kerusakan elemen bangunan secara horizontal terdiri : bagian depan (teras), tengah (kamar utama), belakang (dapur), dan seluruh bangunan (total). Elemen paling banyak terjadi kerusakan adalah bagian tengah vertikal (dinding) dengan $44,44 \%$ dan belakang horizontal (dapur) dengan $55 \%$.

Elemen dinding secara arsitektur pada bangunan sederhana (rumah tinggal) berfungsi sebagai penyekat ruang relatif rapuh menghadapi bahaya cuaca ekstrem. Dinding sebagai elemen penyekat ruang hendaknya mendapatkan perhatian dalam proses konstruksinya mengingat dinding secara struktur juga dapat berfungsi menambah kekakuan dan kekuatan bangunan dalam menahan beban.

Tipikal bangunan rumah tinggal menempatkan pembagian zona denah bangunan menjadi 3 bagian yakni bagian depan yang diwakili oleh area teras, bagian tengah dengan fungsi-fungsi ruang utama, dan bagian belakang dengan zona servis seperti dapur, kamar mandi, dan area cuci. Area servis seringkali dibangun hanya berorientasi menyelesaiakan permasalahan fungsi dengan mengesampingkan kualitas dan kekuatan konstruksi. Kurang terlihat secara visual dapat menjadi alasan mengapa kualitas konstruksi zona belakang bangunan kurang begitu diperhatikan sehingga banyak mengalami kerusakan (Gambar 10). 


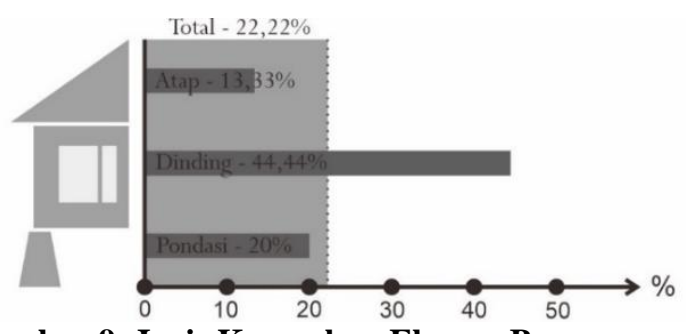

Gambar 9. Jenis Kerusakan Elemen Bangunan (Vertikal)

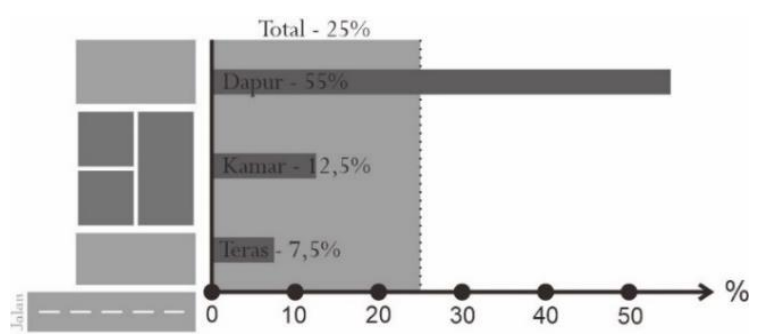

Gambar 10. Jenis Kerusakan Elemen Bangunan (Horizontal)

Persentase rusak total mencapai lebih dari $20 \%$ merupakan angka yang cukup tinggi, dimana sebagian besar diakibatkan karena hanyut dan tertimbun tanah. Risiko kerusakan sangat ditentukan oleh lokasi bangunan. Keberadaan tebing yang rawan longsor di sekitar bangunan dan kondisi tanah yang labil merupakan bagian dari faktor lokasi tapak bangunan yang menentukan risiko kerusakan terjadi. Selain itu, konstruksi pondasi bangunan hendaknya diperhatikan menyesuaikan dengan kondisi tanah setempat terutama apabila daya dukung tanah kurang baik.

\section{Simpulan}

Risiko terjadinya cuaca ekstrem begitu besar di Indonesia sehingga harus ada perhatian mengenai cara mengantisipasi dan mengurangi dampak kerugian materiil dan korban jiwa. Hasil kajian menunjukkan adanya hal-hal yang harus dilakukan diantaranya:

- Sebaran kerusakan bangunan mengarah ke wilayah kontur curam dan dataran tinggi sehingga harus ada kewaspadaan tinggi pada lokasi tersebut, seperti halnya di wilayah bagian timur Kabupaten Bantul, juga di wilayah lain Indonesia yang memiliki topografi yang serupa.

- Area terdampak cuaca ekstrem sangat luas, walaupun kerusakan/kerugian tidak terjadi merata di seluruh wilayah, sehingga perlu kewaspadaan bersama seluruh elemen masyarakat di wilayah potensi tinggi cuaca ekstrem.

- Konstruksi bangunan hendaknya memperhatikan pemilihan kualitas bahan dan kekuatan konstruksinya di samping hasil finising visual yang baik.

- Perlu perhatian pada elemen-elemen bangunan terutama bagian belakang bangunan (dapur \& kamar mandi), dinding, dan pondasi dalam menghadapi cuaca ekstrem untuk mengurangi resiko terjadi kerusakan.

- Kelompok rentan yang perlu diperhatikan adalah usia lanjut dan anak-anak agar risiko korban jiwa dapat diminimalisir atau bahkan dihindari.

\section{Ucapan Terimakasih}

Terimakasih diucapkan kepada Badan Penanggulangan Bencana Daerah (BPBD) Kabupaten Bantul yang telah memberikan datadata survey bencana dalam tulisan ini, sehingga penulis dapat menyelesaikan kajiannya. Semoga tulisan ini dapat memberikan manfaat dalam upaya mitigasi bencana khususnya yang berkaitan dengan bencana hidrometereologi di Kabupaten Bantul khususnya dan di Indonesia pada umumnya.

\section{Daftar Pustaka}

1. Bawono, A. S. (2016) 'Studi Kerentanan Bangunan Akibat Gempa: Studi Kasus Perumahan Di Bantul', Semesta Teknika, 19(1), pp. 90-97.

2. BNPB (2014) Rencana Nasional Penanggulangan Bencana 2015-2019, Rencana Nasional Penanggulangan Bencana 2015-2019. Indonesia. Available at:

https://www.bnpb.go.id//uploads/renas/1/ BUKU RENAS PB.pdf.

3. BNPB (2017) Potensi Ancaman Bencana, bnpb.go.id. Available at: https://bnpb.go.id/potensi-ancamanbencana.

4. BNPB (2018) Indeks Risiko Bencana Tahun 2018. Jakarta: Direktorat Pengurangan Risiko Bencana BNPB.

5. Iryanthony, S. B. (2015) 'Pengembangan Modul Kesiapsiagaan Bencana Angin Puting Beliung', Pengembangan Modul Kesiapsiagaan Bencana Angin Puting Beliung Untuk Mahasiswa Pendidikan Geografi Unnes, 12(2), pp. 143-154. doi: 10.15294/jg.v12i2.8002.

6. Paimin, Sukresno, I. B. P. (2009) Teknik Mitigasi Banjir dan Tanah Longsor. Balikpapan: Tropenbos International Indonesia Programme.

7. RI (2007) UU Nomor 24. Indonesia. 
8. Widyaningrum, G. L. (2018) Kerap Terjadi, Bencana Hidrometeorologi Juga Perlu Kita Waspadai, nationalgeographic.grid.id. Available at: https://nationalgeographic.grid.id/read/13 949980/kerap-terjadi-bencanahidrometeorologi-juga-perlu-kitawaspadai?page $=$ all.

9. Yuniarta, H., Saido, A. P. and Muslih Purwana, Y. (2015) 'Kerawanan Bencana Tanah Longsor Kabupaten Ponorogo', Matriks Teknik Sipil, pp. 194-201. 
